\title{
RACIONALIZAÇÃO E SECULARIZAÇÃO DA MORTE: Contribuições Sociológicas à Luz de uma Metodologia Weberiana.
}

\author{
RATIONALIZATION AND SECULARIZATION OF DEATH: SOCIOLOGICAL CONTRIBUTIONS IN THE
}

LIGHT OF A WEBERIAN METHODOLOGY.

\begin{abstract}
Árife Amaral Melo.
\section{RESUMO}

Este artigo propõe-se a realizar uma análise sociológica de cunho weberiano a respeito da relação existente entre o processo de racionalização e secularização da morte e as mudanças estéticas na morfologia tumular, em que percebe-se muito mais seu caráter utilitário do que sacral. Nesse sentido, a pesquisa lança seu olhar nos processos sociais envolvidos nessa situação, procurando identificar que tais variações no cenário cemiterial refletem também uma relação com o processo de mudanças significativas na sociedade, a qual se vê diante de "facilidades modernas" que poupam os enlutados de manter contato direto com seus entes recém-falecidos, proporcionando uma realidade na qual se mantém uma espécie de mercado da morte, que sobrevive e de certa maneira contribui para uma nova significação das práticas funerárias, no qual sua dimensão religiosa cede lugar aos processos racionalizados no trato com a morte.
\end{abstract}

PALAVRAS-ChAVE: Secularização. Racionalização. Morte. Weber.

\begin{abstract}
This article proposes to realize a Weberian sociological analysis regarding the relationship between the process of rationalization and the secularization of death and the aesthetic changes in the morphology of the tomb, in which one perceives much more its utilitarian rather than sacral character. In this sense, the research looks at the social processes involved in this situation, trying to identify that such variations in the cemetery scenario also reflect a relationship with the process of significant changes in society, which is faced with modern facilities that save the mourners to maintain direct contact with their recently deceased entities, providing a reality in which a kind of death market is maintained and survives, and in a certain way, contributes to a new meaning of funeral practices, in which its religious dimension gives way the rationalized processes in dealing with death.
\end{abstract}

KEYWORDS: Secularization. Rationalization. Death. Weber.

Tratar de aspectos sociológicos da morte implica em examinar o impacto que a finitude da vida exerce sobre a conduta religiosa e/ou racional, bem como as repercussões que esse fato desencadeia na sociedade. Para isso, é importante delimitar alguns pontos-chave no que se refere a esse evento, tornando possível sua análise que, nesse caso, se sustenta em três pontos fundamentais: a configuração dos cemitérios a partir da prática da inumação; o processo de racionalização/secularização pelo qual tais práticas passam, e a mercantilização da morte como subproduto dessa relação. Como norte dessa análise será utilizada a perspectiva compreensiva weberiana, que dedica especial atenção a esses fatores,

Professor do Instituto Federal do Paraná - Campus Jacarezinho. Mestre em Ciências Sociais pela FFC - UNESP Campus de Marília. Doutorando em Ciências Sociais pela FFC - UNESP Campus de Marília. E-mail: arifeam@gmail.com 
principalmente no que se refere aos mecanismos racionais e burocráticos que permeiam as fundamentações religiosas sobre a morte.

Pode-se partir da premissa de que os agentes sociais, no decorrer de sua trajetória deixam, invariavelmente, uma herança social (cultura) que permite aos seus sucessores sua reprodução, rejeição ou ressignificação, quer seja material ou abstratamente. A vida, dotada de sentido, se realiza não somente quando se pode expressar seus valores, mas também, quando outros o fazem por elas. É o caso da morte: pode-se observar a vida expressada naquilo que se pretende preservar após o momento final, não somente para o ente que se foi, mas para a sociedade dos viventes, conforme nota-se na constituição dos cemitérios.

O hábito de aplicar um fim que se deseja dar ao corpo (enterrar, sepultar, cremar, embalsamar, etc.) compõe um elemento imanente no processo de socialização, pois permite que se construam símbolos de diferenciação social. Isso pode ser observado nos túmulos mais antigos das necrópoles (numa comparação entre o séc. XX e XXI), nos quais é perceptível a necessidade de destacar o jazigo perante os demais, transformando o cemitério num local de variedade estética (mausoléus, estatuário e amplitude do jazigo são determinantes nessa análise) que o transforma em um museu a céu aberto. Porém, é possível notar também o enfraquecimento dessa variedade de elementos, influenciados pelo processo de ressignificação sofrido pela morte.

A dor do luto encontra seu escape na concentração em um local onde todos depositam suas saudades e memórias sobre o ente que ali jaz. Considerando o cemitério como um espaço macabro de socialização, entende-se que a busca através do rito funerário possui a significação necessária para suportar a perda: lembrar e homenagear aqueles que se foram para assim eternizá-los; cultivar não somente uma memória afetiva que projete para os vivos as virtudes ou grandezas daqueles ali inumados, como também uma motivação de caráter valorativo sobre a história de si e dos seus, que sejam próximos dos seus mortos.

Para debruçar-se sobre um objeto de análise sociológica complexo como é a morte, a perspectiva é imprescindível. Em se tratando da importância de tais agentes na construção de um imaginário social, é importante saber quais abordagens mais viáveis devem ser estabelecidas, haja vista que metodologicamente não é aconselhável ao pesquisador tergiversar sobre a abordagem que deseja enfatizar em sua investigação. Para tanto, apesar de diversos autores abordarem os aspectos da morte no processo de socialização, a contribuição de Weber é de suma importância, considerando sua dedicação à investigação sociológica em torno da religião e do processo de racionalização da mesma, afetando direta e indiretamente a sociedade como um todo. Diretamente, porque o espaço de lamentação e saudade que é o cemitério está intimamente vinculado às nuances religiosas do ato de depositar ali o 
cadáver e lhe prestar homenagens. De certa forma, isso implica a prática de um ritual conectivo e reflexivo que remete a uma esfera transcendental, que seria a passagem da vida para a morte. Indiretamente porque a forma como esses elementos são dispostos e dotados de algum simbolismo não é estagnado, mas dinâmico, e a influência de uma sociedade profundamente racionalizada reflete até mesmo na maneira de como os vivos tratam seus mortos.

Numa perspectiva weberiana de ação social relacionada à morte, que implica determinado sentido ao ato de preservar na lápide a memória dos seus, existe uma perspectiva de reconhecimento projetado ao futuro, numa dimensão íntima, mas que visa notoriedade e reconhecimento de outros (os vivos). Dada essa situação, não se excetuam outros núcleos sociais (em sua maioria familiares) que desenvolvem o mesmo mecanismo de significação, criando uma situação na qual os mortos ocupam o mesmo espaço, porém determinado e significado pelos vivos. Tem-se então uma relação intimista do homem com a morte (impulsionada pela concepção religiosa de "alma") emanada num significado intrínseco no que se refere ao inconformismo de que a existência humana seja finita: é necessária a intervenção perante a morte; é preciso controlá-la, mesmo que não se possa evitá-la. O cessar do corpo não é suficiente para delimitar sua finitude. $O$ aspecto não tangível daquele que se foi permanece, e portanto deveria, a priori, ser honrado, purificado, bem como conduzido a um local e instalações apropriadas.

Apesar do sofrimento da perda e a busca pelo descanso dos entes sejam uma questão típica de um ethos religioso, os fatores materiais também exercem influência sobre as ações feretrais. Segundo Weber (1974, p. 310), "é claro que o modo de vida determinado religiosamente é, em si, profundamente influenciado pelos fatores econômicos e políticos que operam dentro de determinados limites geográficos, políticos, sociais e nacionais”. Destarte, a cidade dos mortos não é composta como mero centro religioso de contemplação e luto. Ali se localizam expressões identitárias e culturais que denotam a influência das transformações da sociedade ad extra luto e da morfologia tumular, em que o processo de secularização e de apropriação dos mecanismos econômicos se entrelaçam.

A partir dessa apropriação e do processo racionalizante em torno da morte e da constituição da morfologia tumular, gera-se uma mudança naquele sentido sacral para uma situação na qual o luto e sepultamento são cada vez mais passíveis de movimentar uma logística e um mercado. Nesse sentido, o trato dado aos mortos possibilita o surgimento de novos profissionais especializados na tarefa de proporcionar aos cadáveres os devidos cuidados, tanto no que se refere à sua composição durante o velório quanto ao local em que serão depositados. Se antes essas atividades profissionais eram instituídas de maneira quase informal, hoje estes 
profissionais têm à disposição processos formativos através de cursos especializados, além de serem reconhecidos pelo Ministério do Trabalho na $\mathrm{CBO}{ }^{1}$ (Classificação Brasileira de Ocupações), ou seja, da saída do necrotério até a inscrição do epitáfio estão evolvidas pessoas que fazem da atividade voltada aos mortos um meio de vida, no qual estes profissionais isentam amigos e parentes, antes responsáveis por todo o trabalho gerado pela morte, para que se dediquem exclusivamente à dor da perda e às homenagens devidas aos entes que partiram. Para que isso ocorra, processos racionais são desenvolvidos a tal ponto que sua influência pode ser percebida tanto nas técnicas empregadas na lide com os mortos, bem como no local onde estes serão sepultados, num processo secularizado de significação.

\section{A INUMAÇÃO E A MORFOLOGIA TUMULAR}

A prática da inumação é valorativa, simbólica e legitimante. A ordem social estabelecida interfere diretamente na maneira como os vivos tratam os seus mortos, e isso ocorre fortemente no âmbito religioso: a relação entre a religião e a legitimação se dá no que se refere à utilização dos preceitos religiosos como forma ampla de delimitar os aspectos sacrais dos não sacrais. Dessa maneira é estruturada a formação da necrópole, onde o rito do luto seria o fator demonstrativo da morte do ponto de vista religioso; mas concomitante a isso é também o da construção de um aparato memorial que reflita os valores sociais, morais e simbólicos das famílias que ali jazem e dos seus descendentes que ali cultuam sua memória. Naquele local erigido pelos seus não há somente a superação da morte, mas também, a capacidade de demonstrar sua presença no decorrer dos tempos. Segundo Berger,

[...]A legitimação religiosa pretende relacionar a realidade humanamente definida como a realidade última, universal e sagrada. As construções da atividade humana, intrinsecamente precárias e contraditórias, recebem assim, a aparência de definitiva segurança e permanência. (BERGER, 1985, p. 48-49).

Até a segunda metade do século XIX, particularmente no Brasil, a morte se apresentava como um evento intimista, dada a relação de proximidade entre vivos e mortos num espaço muito próximo, haja vista que não raro o enterro era realizado em locais hoje considerados impróprios, como nos fundos da casa ou da fazenda.

\footnotetext{
${ }_{1}^{1}$ Segundo a Classificação Brasileira de Ocupações, de 2002, no título 5165-05 estão os Agentes Funerários, que incluem os tanatopraxistas, auxiliares de funerária e atendentes funerários, cuja descrição sumária é: "Realizam tarefas referentes à organização de funerais, providenciando registros de óbitos e demais documentos necessários. Providenciam liberação, remoção e traslado de cadáveres. Executam preparativos para velórios, sepultamentos, conduzem o cortejo fúnebre. Preparam cadáveres em urnas e as ornamentam. Executam a conservação de cadáveres por meio de técnicas de tanatopraxia ou embalsamamento, substituindo fluidos naturais por líquidos conservantes. Embelezam cadáveres aplicando cosméticos específicos.
} 
Religiosamente determinado pelo catolicismo, o local ideal para o enterro seria nas proximidades da Igreja, chamado de enterro ad sanctum; e caso o morto fosse figura ilustre, poderia ser sepultado até mesmo dentro do templo. A passagem da inumação doméstica para as igrejas e posteriormente para os cemitérios convencionais já sinaliza uma ressignificação relevante no que se refere ao trato a ser dado aos corpos, não mais desejáveis ao convívio familiar. Se antes o leito de morte era nas dependências da casa, bem como sua inumação, agora a morte ocorre no hospital e o cadáver é encaminhado às necrópoles.

Segundo Ariés (1975) os ritos fúnebres, além de demonstração de respeito à memória dos mortos era também uma forma de afastamento, para que os mortos não viessem a importunar os vivos. Estaria assim, selada a divisão de espaço entre os vivos e os mortos, de modo que os mortos pudessem ficar cada vez mais apartados, não só espiritual, mas também fisicamente:

Apesar da familiaridade com a morte, os antigos temiam a proximidade dos mortos e os mantinham à distância. Honravam as sepulturas - nossos conhecimentos das antigas civilizações pré-cristãs provêm em grande parte da arqueologia funerária, dos objetos encontrados nas tumbas. Mas um dos objetivos dos cultos funerários era impedir que os defuntos voltassem para perturbar os vivos.

O mundo dos vivos deveria ser separado do mundo dos mortos. É por isso que em Roma a Lei das Doze Tábuas proibia o enterro in urbe, no interior da cidade. O código Teodosiano repete a mesma proibição, a fim de que seja preservada a sanctitas das casas dos habitantes. (ARIÉS, 1975, p. 22).

Partindo do pressuposto de que a morte não faz nenhuma distinção para tirar os vivos do convívio com os seus, ela precisa, nas palavras de Ariés, ser domada. Para isso os mortos passam por um processo: os defuntos estão proibidos de dividir espaço com os vivos na casa onde habitavam, devendo ser destinados a um outro espaço, afastado. Posteriormente, retornam a ter contato com os vivos pela via do enterro ad sanctus, nos quais a Igreja passa a ser o elo entre vivos e mortos que desejam uma morte mais próxima de Deus, até que, finalmente, sob a influência da racionalização e da secularização, passam a ser outra vez designados a espaços exclusivos, compondo o padrão atual do que hoje se compreende o cemitério. Durante essa passagem, a necrópole passa a ser não somente um local religioso de cultivo da memória dos antepassados, mas também um local dos que vivem e projetam suas aspirações e concepções de mundo, através da composição coletiva da cidade dos mortos, ou seja, apesar de ser um solo sagrado, os cemitérios possuem fatores sociológicos e econômicos relevantes para a constituição dos mesmos, e, de certa maneira, até lhe conferem uma razão de ser.

No caso brasileiro, o modelo de enterro ad sanctum e o doméstico deixam de ser comuns e passam a ser questionados sob a justificativa científica de que a 
proximidade entre os cadáveres e os vivos não seria saudável para a população. Gilberto Freyre observa os questionamentos sobre a viabilidade da inumação próxima à casa dos grandes fazendeiros, pois eram

(...) capelas que eram verdadeiras puxadas da habitação patriarcal. Os mortos ficavam na companhia dos vivos: até que os higienistas já no segundo Império, começaram perguntar: "até quando persistirá a triste prerrogativa dos mortos envenenarem a vida dos vivos? (FREYRE, 2005, p. 526).

A tese higienista pode ser considerada um dos pontos iniciais do processo de racionalização da morte, haja vista que a preocupação não se dá mais referente ao aspecto místico do corpo, mas sim ao seu aspecto físico: o corpo mal depositado pode ser fonte de inúmeros danos àqueles que circulam próximos às suas sepulturas. Portanto, é necessária a criação de um local mais apropriado para o destino dos cadáveres. $\mathrm{O}$ enterro ad sanctum deixa de ser uma prioridade e o cemitério passa a ser o destino dos corpos que nessa situação, se tornaram indesejáveis para o convívio com os vivos. Observa-se então um novo paradigma: órfãos do terreno santo que era proporcionado pela Igreja, os enlutados devem fazer dos cemitérios seu novo campo santo, mas para isso terão que trazer para si a responsabilidade de constituir um espaço adequado e funcional. Isso porque questões como saúde pública, higiene e a separação Igreja-Estado são determinantes na construção desses locais e do processo de secularização pelo qual passa a morte, bem como sua racionalização. Nesse bojo encontra-se a influência do próprio capitalismo, que se apropria das demandas racionalizadas, direcionando as necessidades envolvidas sobre a morte, que acabará acarretando nas mudanças estéticas e conceituais observadas nos cemitérios públicos e particulares, anulando ou suprimindo de maneira progressiva a finalidade religiosa das necrópoles.

\section{A RACIONALIZAÇÃO DA MORTE E A SECULARIZAÇÃO}

Os procedimentos sociais envolvendo a morte (luto, inumação, constituição de memorial) perpassa por fatores a priori na questão da religiosidade. Desde o momento do morrer até o tratamento para com o cadáver eram implicados fatores determinados por uma religião, e no caso brasileiro, principalmente denominações cristãs. A simbologia da cruz e do crucifixo, no caso católico, remete à esperança da salvação das almas e do culto a elas. No entanto, estes elementos não deixam, concomitantemente, de serem afetados por elementos sociais racionalizados e por conseguinte, secularizantes. Historicamente, como já foi afirmado aqui, a secularização do Estado bem como a forte influência do capitalismo na vida cotidiana (e isso inclui o luto e a morte) foram importantes para as transformações que se 
observa nessa temática. Weber (2002) faz uma breve localização sobre essas duas esferas que permeiam a sociedade, destacando o escopo de ambas (religião e Estado):

\begin{abstract}
A ação social, especialmente de uma associação será politicamente orientada se, e na medida em que, seu propósito for o de influenciar a liderança de uma associação política, seja para apropriação, expropriação, atribuição ou reatribuição dos poderes governantes. A associação de dominação será chamada de "hierocrática" se, e na medida em que, empregar, para manter sua autoridade, a "coerção psíquica" por meio da concessão ou não de benefícios religiosos (coerção hierocrática). Uma associação hierocrática compulsória com uma organização contínua será conhecida como uma "Igreja" se, e na medida em que, seu quadro administrativo reivindicar um monopólio do uso legítimo da coerção hierocrática. (WEBER, 2002, p. 99).
\end{abstract}

Essa desvinculação "administrativa” em torno do local de enterro, capital antes monopolizado pela Igreja e a partir de então transferido para o Estado, está inserida num processo de racionalização que afeta diretamente as mentalidades envolvidas principalmente no que se refere à forma de se realizar essa prática, ou seja, nesse local agora secularizado, cabe aos vivos dar novo significado e atribuir ao túmulo toda a carga afetiva antes depositada no modelo ad sanctum. Assim surge um novo local de cultivo da memória, em que a simbologia e a estética tumular remetem a uma profunda herança religiosa, não deixando, invariavelmente, de se remeter ao crivo da secularização, pois tais características da conduta são fundamentais para se compreender como determinadas práticas religiosas são notadamente marcadas pela racionalidade, uma vez que existem fatores ad extra que impulsionam o trato com a morte de maneira menos mágica, menos mística, menos religiosa, como é o caso do mercado existente em torno da morte, que será tratado mais adiante.

Para a configuração do modelo cemiterial existente no século XXI, houve um processo social que deflagrou a situação na qual a religião perde não somente esse monopólio sobre os corpos, mas cede espaço para que o espaço cemiterial, apesar de ser um território fundamentalmente de práticas religiosas, seja laico na perspectiva legal. Isso abre um espaço propício para que ocorram profundas mudanças sociais no decorrer da sua história. A Igreja perde espaço físico e ideológico perante a laicização dos espaços fúnebres dos cemitérios. Segundo Pierucci (1998),

A primeira vez que a palavra secularização foi enunciada fora dos muros e dos textos da igreja católica, apontam os pesquisadores em lexicografia, foi para nomear o processo jurídico-político de desapropriação dos bens eclesiásticos em favor dos poderes seculares. (PIERUCCI, 1998, p. 23)

Portanto, a derrota institucional da Igreja impacta sobre o processo de decisão do destino dos corpos, antes sob o controle das autoridades eclesiásticas. Mas agora esse processo se encontra nas mãos da sociedade civil e do Estado, usando como embasamento a ciência e a burocracia. Nesse sentido, a preocupação com os aspectos 
higiênicos que envolviam o fim a ser dado aos cadáveres foi fundamental no processo de afastamento dos locais de sepultamento do convívio com os vivos.

As teorias miasmáticas acreditavam que, assim como os doentes poderiam transmitir doenças às pessoas saudáveis, os corpos sepultados, de maneira relapsa poderiam, durante sua decomposição, gerar determinados gases que seriam nocivos à saúde. Tem-se então um caso de saúde pública, que proporcionou o escopo necessário para o fim da prática do sepultamento sem padronização adequada. Nesse ínterim, surge a normatização dos locais em que serão destinados os corpos, ou o planejamento daquilo que após a segunda metade do século XIX serão os cemitérios laicos que hoje se apresentam. Heuer (2004) aponta a relevância dessa mudança:

Para neutralizar a ação desses gases, uma série de práticas foi estabelecida pelas autoridades higiênicas. A primeira delas foi a separação entre o mundo dos vivos e dos mortos. Se os mortos eram enterrados no meio do núcleo populacional, agora são criados espaços específicos para recebê-los. Surgem então os cemitérios públicos que, obedecendo as novas normas de higiene, vão controlar os corpos e normatizar os enterros. Todo o seu planejamento, arquitetura, organização interna e administração tem como objetivo a minimização da ação mórbida dos miasmas. A medida das sepulturas, as árvores, o muro, os espaços vazios, a capela mortuária, faziam com que os miasmas permanecessem bem longe das populações. Mas além de controlar os miasmas, a construção dos cemitérios também teve outro objetivo. Se até então muitos enterros não entravam na contabilidade mortuária, com o surgimento das novas necrópoles essa situação se modificou. Os cemitérios públicos fizeram parte da estrutura que permitiu conhecer a totalidade de óbitos. Assim, com base nestes números, foi possível desenvolver as medições estatísticas. Esses números eram essenciais para a administração, pois era através da estatística que a população se tornava uma realidade quantificável. (HEUER, 2004, p. 11-12).

Observa-se que a aplicação racionalizada do enterro em local apropriado não abrange meramente $\mathrm{o}$ ato em si da inumação, mas também atende às necessidades de uma sociedade que apesar de secularizada, quer expressar seus valores nas formas tumulares. No entanto, convém ressaltar que esse processo (a racionalização e secularização da morte) não se deve somente a aspectos exógenos, mas também a endógenos, da conduta: partindo do pressuposto de que há uma ação social racional relacionada a valores no trato com os túmulos, bem como no lidar com a dor da perda, na composição dos cemitérios ressalta aos olhos as contradições entre as famílias menos favorecidas e a as famílias elitistas. A suntuosidade dos mausoléus e do estatuário das famílias mais ricas em contraposição aos túmulos mais simples dos mais pobres evidencia na cidade dos mortos as discrepâncias sociais da cidade dos vivos.

Nas necrópoles fica evidente pela arquitetura sofisticada de alguns túmulos, que estes tentam representar a vida de personagens sociais influentes ou de poderio econômico e político, tais como famílias de passado vinculado à nobreza, de uma 
burguesia cafeeira ou industrial e até mesmo congregações religiosas. Representando esses personagens póstumos, são utilizados nos túmulos bustos e estátuas de bronze ou mármore, bem como o mausoléu como símbolo de ostentação em si. Na medida oposta se revela o espaço das famílias menos favorecidas, ocupado por túmulos simples, de arquitetura muitas vezes rústica, mas que propõe representar algum tipo de memorial para aqueles que os visitam, como é o caso das fotografias mortuárias desbotadas, as mensagens nas lápides escritas com tinta já desgastada, ou mesmo a ausência desses adornos, que denota a falta de recursos financeiros para a construção ou manutenção dos jazigos, o fim de uma geração ou esquecimento por parte dos parentes e amigos que entregam esses túmulos às intempéries do clima no passar dos anos. Como acontece com a suntuosidade de uma casa, que pode demonstrar prestígio, sua falta pode ser observada na simplicidade de uma habitação sem recursos arquitetônicos. Ou podem ocorrer os dois processos: o declínio de uma família antes abastada sendo aos poucos diluída pela ação do tempo num jazigo luxuoso, num passado distante.

Nesse sentido, os aspectos visualmente evidentes são impactados com o processo de racionalização. A partir desse ponto de diferenciação na configuração estética dos túmulos, é possível observar nos memoriais mais recentes (considerando-se edifícios tumulares datados da segunda metade do século XX) um processo de transformação estética relevante, no qual a função utilitária desses espaços torna-se mais frequente do que a ostentação tumular pela arquitetura, estatuário ou materiais de construção relativamente caros. A configuração dos túmulos já não representa necessariamente os níveis de poder econômico ou social, pois esse caráter racionalizado sobre a morte tornou-se quase perene: nos túmulos "modernos", há uma certa semelhança, que reside no seu aspecto funcional, no qual vistos à distância não possibilita identificar a qual nível social a família dos mortos ali inumados pertence. Tal observação só pode ser percebida "de perto", quando se nota o tipo de material empregado na confecção das sepulturas, em que mármores e granitos contrastam com materiais comuns da construção civil, tais como azulejos, pisos e revestimentos. É importante observar nos cemitérios uma gama de objetos que simbolizam os mais diferentes processos sociais pelos quais a sociedade dos vivos se organiza ou é organizada, fazendo desses fatores algo que pode ser lido e compreendido na busca dos significados dados pelos indivíduos que compuseram esses locais, pois:

Quando submetidos à leitura, os dispositivos funerários plasmados nos túmulos permitem traduzir não só acomodações e equilíbrios, mas também tensões e mudanças operadas no contexto de um grupo específico ou no corpo social mais amplo; assim como é também capaz de revelar atos institucionais e de condutas sociais e morais diversos, tendo sempre como preocupação dar sentido e significado a alguma coisa. (MOTTA, 2009, p. 74). 
Para tentar compreender essa assinatura social marcada nos cemitérios, é preciso perceber os contrastes que ali se fazem evidentes ou discretos. Esses contrastes, apesar de não serem os únicos determinantes, permitem compreender a divisão entre aqueles que podem e os que não podem manifestar suas homenagens pela ostentação das lápides. Tal divisão existe e é latente, e por isso é necessário observar essas nuances sociológicas ali impressas, delimitando referenciais que possibilitem uma análise mais profunda e que seja também extra muros dos cemitérios, estabelecendo as conexões necessárias com os grupos sociais envolvidos nas vicissitudes dos processos que envolvem o luto, bem como as representações implicadas na construção da memória familiar e social dos que se foram. Procurando identificar um tipo ideal na acepção weberiana do termo, podem-se observar na conjuntura da necrópole alguns sinais que o cemitério cristaliza em forma de processos racionalizados: a) estética: bem como as habitações dos vivos, os mortos cujas histórias são privilegiadas financeiramente as têm refletidas, senão pelo estatuário e ostentação pelo tamanho, no mínimo pelo material utilizado na construção dos jazigos; b) conservação: o item anterior repercute neste, haja vista que não raro é possível encontrar jazigos que já tiveram amplo destaque e que se mantêm, bem como alguns que estão deteriorados pela ação do tempo e já não mais refletem o antigo esplendor. Todavia, os mais simples quando não conservados, beiram a degradação; c) geografia: essa situação pode ser hoje dividida em ainda duas categorias, com o advento do capitalismo moderno sobre a morte: c.1: pode-se perceber que, em geral, a distribuição dos túmulos e mausoléus localiza-se em pontos mais privilegiados, bem como o espaço que ocupam (regiões centrais, na entrada e/ou próximos às ruas mais amplas, facilitando o acesso e a visualização); c.2: a estratificação social pode chegar ao ponto em que se criam espaços exclusivos (novos cemitérios) para que os mortos sejam enterrados junto àquelas famílias cujo poder aquisitivo permite adquirir lotes em cemitérios que se assemelham a condomínios e cujos serviços se assemelham a clubes; d) números de controle: tanto os túmulos mais simples quanto os mais suntuosos são marcados com números (perpétuas) catalogados, que possibilitam o controle burocrático dos enterros bem como a contagem dos mortos.

Percebe-se então uma estrutura relativamente pensada e calculada, cuja influência burocrática sustenta a necessidade administrativa sobre as necrópoles, reforçando ou reproduzindo as relações de poder existentes na sociedade vivente. $\mathrm{O}$ controle sobre o destino dos corpos pela via burocrática condensa a racionalidade aplicada ao cotidiano de maneira que a necrópole não mais se constitui de maneira desordenada, espontânea, caótica. O poder secular delimita os espaços nos quais os 
cultos aos mortos serão praticados. A dedicação weberiana voltada à burocracia já alerta para tal situação, pois

Quando se estabelece plenamente, a burocracia está entre as estruturas sociais mais difíceis de destruir. A burocracia é meio de transformar uma "ação comunitária" em uma "ação societária" racionalmente ordenada. Portanto, como instrumento de "socialização" das relações de poder, a burocracia foi e é um instrumento de poder de primeira ordem - para quem controla o aparelho burocrático. (WEBER, 1974, p. 264).

Tal pragmatismo em torno da morte ilustra um processo de racionalização que não foi exaurido, mas que se renova, no qual a significação da morte, apesar de ainda ter como pano de fundo o questionamento e a inconformidade com a finitude da vida, pode servir de exemplo de como a sociedade moderna, tipicamente capitalista, ressignifica o luto e as condutas em seu entorno, provocando mudanças no establishment religioso, que até então era sustentáculo de uma conduta e mentalidade sociais. Isso ocorre, por exemplo, quando se identifica nas sociedades hodiernas o afastamento dos vivos em relação aos mortos, pelo menos no que se refere ao seu aspecto mais concreto, ou seja, o tratamento dado aos mortos desde o falecimento até a inumação, que traz à tona mais um elemento vinculado a esse processo de racionalização e secularização da morte: o mercado.

\section{A MERCANTILIZAÇÃO DA MORTE}

Apesar da morte possuir um forte apelo religioso sobre os sentimentos dos vivos, o principal objeto envolvido no seu contexto - o cadáver - ficou relegado a um distanciamento cada vez maior conforme a sociedade moderna se aprimora e se relaciona com algumas funcionalidades da vida prática. Aos poucos, o recém-falecido passa de um extremo a outro no processo de socialização: de criatura amada e desejada a ficar entre os seus, passa a ser objeto de asco, de incômodo. Tal afastamento dos vivos em relação aos mortos fica cada vez mais evidente quando se considera que a religião, antes monopolista no trato com a dor dos vivos e na motivação para estes lidarem com seus falecidos, divide hoje espaço com os serviços especializados prestados pelas funerárias aos enlutados.

Um dos fatores que facilitam o crescimento do mercado especializado na morte é a lacuna deixada pelo processo de racionalização da mesma: a dor da perda e sua carga afetiva permanecem, mas os aspectos práticos que a morte implica devem ser guiados pela razão. Nesse sentido, surgem então indivíduos especialistas no trato para com esse objeto indesejável que é o cadáver. Em suma, o morto é amado enquanto uma ideia que permanece na memória, mas seu cadáver é tratado como um fardo, que apesar de ser digno de respeito e de um enterro apropriado, não possui tal dignitude para ser manipulado pelos seus próximos. A manipulação de cadáveres torna-se um 
tabu para a família e amigos. É necessária então a atuação de alguém que não possua nenhum envolvimento afetivo para atenuar o horror que a morte representa, manifestado no corpo sem vida. O cadáver deve estar apresentável; isso inclui o cerne do trabalho dos agentes funerários, tanatopraxistas, necromaquiadores e auxiliares funerários: a maquiagem, a vestimenta apropriada, a disposição do corpo no caixão, o controle dos cheiros que podem ser exalados, o transporte, o enterro e o atendimento aos enlutados, tudo isso executado de maneira mais eficaz possível. Segundo Ariés (1975),

De acordo com as análises precedentes, seríamos tentados a admitir que o interdito que hoje afeta a morte é uma característica estrutural da civilização contemporânea. $\mathrm{O}$ afastamento da morte do discurso e dos meios familiares de comunicação pertenceria, como a prioridade do bem estar e do consumo, ao modelo das sociedades industriais. (ARIÉS, 1975, p. 163).

Ao encontro dessas atividades profissionais que envolvem a morte, amplia-se o leque de produtos e serviços oferecidos, tal qual qualquer outro empreendimento, cujo argumento baseia-se sempre no apelo à amenização do sofrimento já causado pela morte, cuja responsabilidade deve ser terceirizada. Observa-se nesse caso o surgimento e a consolidação de atividades profissionais como a tanatopraxia, o surgimento de cemitérios particulares, crematórios, planos funerários e a produção de caixões e urnas funerárias em escala industrial. Essa solução racional se expande na composição dos espaços fúnebres, na sua construção, mas sobretudo na modernização desses locais, refletindo uma mise à jour do processo de enlutamento, na qual a modernidade oferece condições específicas que conduzem a morte a uma instância cada vez mais secularizada, mas primando pelos valores estéticos como forma de suavizar o aspecto macabro relacionado aos procedimentos fúnebres.

Os cemitérios particulares, ainda que incipientes no cenário brasileiro, apresentam uma importante participação no processo de racionalização, secularização e mercantilização da morte. Cemitérios-parques e cemitérios verticais, visando ampliar seu mercado, não costumam utilizar símbolos religiosos ou qualquer outros símbolos, numa configuração minimalista, funcional.

Ao final do século XX, os cemitérios de tipo parque ganharam espaço entre os vivos. Os símbolos religiosos são, então, retirados e os túmulos suntuosos também perdem lugar. O espaço destinado aos mortos torna-se secular à medida que a morte passa a caracterizar uma completa finitude, e desvincula-se das explicações da pós-vida e continuidade do homem. O cemitério torna-se, assim, um parque, um jardim, algo secularizado, lugar de neutralidade. Já no século XXI os cemitérios verticais iniciam um tímido crescimento. Nesse ponto, a morte é mais intensamente laicizada, e sua relação com a religião sofre um enfraquecimento significativo. (THOMPSON, 2015, p. 11). 
Além dessa característica marcante, os cemitérios particulares não mais se limitam a apenas servirem de local de destino e de trato aos cadáveres. São oferecidos diversos tipos de serviços atrelados à compra do jazigo ou dos ossários, como atendimento psicológico aos enlutados, salas climatizadas, refeitório, hospedagem e até mesmo a cremação.

A cremação, enquanto prática funerária, apesar de não ser ainda tão acessível como a aquisição de jazigos e planos funerários, também elimina significativamente a simbologia sacral, bem como a utilização de um local de culto específico. No entanto, a longo prazo esse é justamente um dos atrativos para quem possui recursos suficientes para adquirir esse serviço, pois as cinzas, uma vez dispostas em uma urna cinerária, não necessitam de um espaço cemiterial que demandaria uma taxa mensal, como é o caso dos jazigos em cemitérios particulares, que exigem uma manutenção constante. Além disso, são também oferecidos outros serviços associados à cremação, como por exemplo a transformação de alguns gramas de cinzas em jóias ou obras de arte, ressignificando racionalmente o papel que o cadáver desempenha, principalmente no que se refere à proximidade com os vivos. Nesse caso, os mortos que passarem pelo processo de cremação podem, se for da vontade dos familiares, "voltar para casa" ou serem espalhados em locais escolhidos por eles ainda em vida, como em alguns casos em que se jogam as cinzas ao mar ou um local que era de apreço por aqueles que faleceram. Todavia, culturalmente a cremação ainda não representa o fim dos cemitérios, mas apenas uma alternativa à inumação, podendo-se afirmar que

Por fim, com a diminuição da popularidade dos cemitérios convencionais, com suas cruzes e anjos, que já foram considerados lugares ideais para a família prestar as homenagens aos mortos, a cremação parece ganhar adeptos e crescem os investimentos nesse setor. Uma forma de ruptura moderna que parece esconder o corpo, com a supremacia de pequenos ornamentos e discrição no lugar de um túmulo monumental. (CASTRO, 2012, p. 149).

Esse viés pragmático sobre a morte repercute diretamente na configuração das formas tumulares dos cemitérios tradicionais, haja vista que é notória a diferenciação entre túmulos antigos (tomando como recorte os cemitérios públicos até metade do século XX) e atuais (metade do século XX até início do séc. XXI) no Brasil. Percebe-se isso numa diluição cada vez maior com relação à estética, na qual o estatuário e a simbologia nas pedras e demais materiais utilizados são substituídos por um padrão tipicamente funcional e de pouca expressão arquitetônica: hexaedros com pouco ou nenhum acessório, acrescidos de uma ou mais placas determinando o nome, data de nascimento/falecimento, e, quando ocorre, alguma frase bíblica geralmente sem nenhuma menção à memória do falecido. Essa configuração se deve, por vezes, a uma 
indústria também voltada para esse mercado. Artistas e artesãos que antes dedicavam uma parte de seu ofício à construção dos jazigos são substituídos por marmorarias, construtores e setores da indústria voltados para artigos fúnebres. Em se tratando de cemitérios particulares, adota-se um modelo no qual a memória do falecido é reforçada apenas por uma placa fixada no solo, geralmente gramado, sem nenhuma expressão artística ou arquitetônica. Nesses casos, a preocupação maior reside no atendimento aos enlutados, oferecendo serviços e estruturas confortáveis para os presentes durante o velório, numa nítida tentativa de mostrar que é possível essa atenuação da dor pela via econômica, do consumo, ou até mesmo da ostentação. O oposto também é válido: em sua maioria, os túmulos contemporâneos são notadamente marcados por uma simplicidade rústica e sua confecção se baseia na construção civil: revestimento de cerâmica barata, reboco pintado e em alguns casos, um oratório despretensioso do ponto de vista artístico. Jazigos produzidos com material simples por pessoas simples. Porém é interessante observar que esse padrão estético desses jazigos acabam servindo de modelo até mesmo para aqueles com poder aquisitivo maior, que nessa situação não mais primam por extravagâncias artísticas ou arquitetônicas nos túmulos, mas preferem transmitir o poder econômico através da nobreza dos materiais: grandes placas de granito ou mármore compõem a formação desses jazigos cuja estética à distância se assemelha aos mais simples. Destarte, observa-se que independentemente de fatores de classe social, o processo de secularização pela qual a morte e os cemitérios passam é cada vez mais evidente, tanto dentro quanto fora dos muros da necrópole.

As relações sociais imbricadas sobre a morte e esse modelo cada vez mais consolidado de formação das necrópoles são resultado de um intenso processo de racionalização, que por sua vez reflete a secularização como mecanismo que abrange muitos aspectos da conduta e dá significado a ela. Segundo Pierucci (1998),

"Secularização" então, passa por acentuada extensão semântica e torna-se uma categoria histórico-filosófica portadora da pretensão de interpretar todo o curso da história universal como gênese da nossa ocidental modernidade sociopolítica e tecnocientífica. Nesta nova e expandida acepção, a secularização tem relação íntima com o processo de história do espírito e da sociedade que também por essa época passa a ser pensado como emancipação da sociedade burguesa. (PIERUCCI, 1998, p. 23).

A atitude em relação à morte e a sua imagem em nossas sociedades não podem ser completamente entendidas sem referência a essa segurança relativa e à previsibilidade da vida individual que a ciência, a técnica e o mercado dedicam à expectativa de vida correspondentemente maior. A vida tornou-se mais longa e desejada, e a morte é indesejável, e portanto deve ser procrastinada ao máximo. A morte não é mais corriqueira, mas dissimulada em forma de evento surpreendente. 
Ficou mais fácil esquecer a morte no curso normal da vida, pois até mesmo a atenuação desse evento "inesperado" e o seu entorno, podem ser comprados, evitando os dissabores cotidianos relacionados à morte.

\section{CONSIDERAÇÕES FINAIS}

É visível na sociedade capitalista que a influência de elementos não-religiosos interferem diretamente na composição de um imaginário religioso a priori, mas não necessariamente chega a transformá-lo em outra instância. Via de regra, a morte ainda significa para a sociedade ocidental um momento de dor, reflexão e questionamento sobre os aspectos imateriais do que há depois do momento derradeiro. Contudo, apesar de sua essência se manter, praticamente tudo o que há de acessório em torno da morte foi assimilado e ressignificado pelas transformações da sociedade moderna. Nesse contexto, há um fato novo talvez ainda não explorado suficientemente pelas ciências humanas: a memória coletiva , antes cristalizada nas lápides dos túmulos, torna-se cada vez mais diluída pela busca formal e pragmática de se dar destino aos corpos sem vida, repassando essa responsabilidade a estranhos. Como consequência, os cemitérios passam cada vez mais da condição de museus a céu aberto para a situação de departamento de arquivos, onde a verdadeira preocupação reside nos dados cadastrais do morto (nome, nascimento, morte), do que necessariamente sua memória para a posteridade. Reserve-se essa crítica ao modelo brasileiro, cuja herança católica foi fortemente responsável por esse modelo monumental de jazigos, mas que, sob a influência racionalizante do processo de secularização, cede lugar agora para um modelo funcional.

Sob a ótica de Weber é possível observar como essa relação salta aos olhos: o sociólogo alemão dedicou parte de seu trabalho à análise do enrijecimento da racionalidade capitalista como forma de controle da ordem social pela via burocrática, enfraquecendo as expressões mais autênticas de relação com a vida e com a morte, valorizando o viés do cálculo, da relação custo/benefício em detrimento da autonomia. Nisso, a racionalização do mundo material (Estado e/ou mercado) se move sobre o cotidiano, gerando aquilo no qual o autor ilustra com uma brilhante metáfora: a "jaula de ferro". Pode-se, a partir dessa figura de linguagem, ilustrar que a mesma situação se dá com essa nova configuração da morte e das necrópoles: assim como a jaula aprisiona, os novos modelos de produtos vinculados à morte também $o$ fazem. Aquele túmulo sem expressão e usual também é uma jaula, que tira da conduta perante a morte sua riqueza de representações culturais em troca do controle das frustrações (inevitáveis) que engendram um funeral.

REFERÊNCIAS

INTERAÇÕES, BELO HORIZONTE, BRASIL, V.12 N.22, P. 393-408, AGo./DEZ. 2017 
ARIÉS, Philippe. História da Morte no Ocidente. Lisboa: Ed. Teorema, 1975.

ARIÉS, Philippe. O homem perante a morte. Lisboa: Ed. Europa-américa, 2000, p. 45.

BERGER, Peter. O Dossel Sagrado. São Paulo: Ed. Paulinas, 1985, p. 181-208.

BRASIL. Classificação Brasileira de Ocupações. Ministério do Trabalho, 2017. Disponível em: http://www.mtecbo.gov.br/cbosite/pages/pesquisas/BuscaPorTitulo Resultado.jsf >. Acesso em: 14 nov. 2017.

CASTRO, Elisiana Trilha. "Ao pó retornarás": um olhar sobre os crematórios e a morte contemporânea. In: Caderno de Pesquisa Interdisciplinar em Ciências Humanas. Florianópolis, v. 13, n. 102, p. 135-152, jan./jun. 2012.

FREYRE, Gilberto. Casa-Grande e Senzala: formação da família brasileira sob o regime da economia patriarcal. São Paulo: Ed. Global, 2005, p. 526.

HEUER, Johanna Wolfman. A normatização dos sepultamentos em nossa senhora do desterro: uma história funerária. Dissertação (Mestrado) - Programa de Pós-graduação em História, Universidade Federal de Santa Catarina, Florianópolis, 2004, p. 11-12.

MOTTA, Antônio. Formas tumulares e processos sociais nos cemitérios brasileiros. In:

Revista Brasileira de Ciências Sociais, $n^{0} 71,2009$.

PIERUCCI, Antônio Flávio. Secularização segundo Max Weber. In: SOUZA, Jessé (org.) A Atualidade de Max Weber. Brasília, Ed. UNB, 1998.

THOMPSON, Barbara. Cemitérios verticais, espaço urbano e meio ambiente: o novo discurso científico universitário de incentivo à verticalização do cemitério e à cremação. Primeiros Estudos, São Paulo, n. 7, p. 07-26, dez. 2015.

WEBER, Max. Conceitos básicos de Sociologia. São Paulo: Centauro, 2002.

WEBER, Max. Burocracia. In: Ensaios de Sociologia. Rio de Janeiro: Zahar Editores. 1974 .

WEBER, Max. Rejeições religiosas do mundo e suas direções. In: Ensaios de Sociologia. Rio de Janeiro: Zahar Editores, 1974.

WEBER, Max. A psicologia social das religiões mundiais. In: Ensaios de sociologia. Rio de Janeiro: Zahar Editores, 1974. 